\title{
Oxygen-ozone treatment and COVID-19: antioxidants targeting endothelia lead the scenery
}

\author{
Angelica Varesi ${ }^{1,4} \cdot$ Salvatore Chirumbolo ${ }^{2} \cdot$ Giovanni Ricevuti ${ }^{3}$ (i)
}

Received: 5 August 2021 / Accepted: 28 September 2021 / Published online: 22 October 2021

(c) Società Italiana di Medicina Interna (SIMI) 2021

$\begin{array}{ll}\text { Abbreviations } \\ \text { ACE2 } & \text { Angiotensin converting enzyme-2 } \\ \text { ARDS } & \text { Acute Respiratory Distress Syndrome } \\ \text { ARE } & \text { Antioxidant response element } \\ \text { CAMs } & \text { Cell adhesion molecules } \\ \text { COX2 } & \text { Cyclooxygenase 2 } \\ \text { CRP } & \text { C-reactive protein } \\ \text { eNOS } & \text { Endothelial-nitric oxide synthase } \\ \text { GCL } & \text { Glutamate cysteine ligase } \\ \text { gamma GCS } & \text { gamma-glutamyl cysteine synthetase } \\ \text { GST } & \text { Glutathione S transferase } \\ \text { 4-HNE } & \text { 4-Hydroxynonenal } \\ \text { HO-1 } & \text { Heme-oxygenase 1 } \\ \text { ICAM-1 } & \text { Intracellular adhesion molecule 1 } \\ \text { IFN } & \text { Interferon } \\ \text { IL-1 beta } & \text { Interleukin-1beta } \\ \text { iNOS } & \text { Inducible nitric oxide synthase } \\ \text { LFA-1 } & \text { Lymphocyte function-associated antigen 1 } \\ \text { NETs } & \text { Neutrophil extracellular traps } \\ \text { NF-kB } & \text { Nuclear factor Kappa Beta } \\ \text { NQO1 } & \text { NAD(P)H quinone oxidoreductase 1 } \\ \text { Nrf2 } & \text { Nuclear factor erythroid 2-related factor 2 } \\ \text { ROS } & \text { Reactive oxygen species } \\ \text { STEMI } & \text { ST elevation myocardial infarction } \\ \text { VCAM-1 } & \text { Vascular cell adhesion molecule 1 } \\ \text { VLA-4 } & \text { Very late antigen-4 } \\ & \end{array}$

Giovanni Ricevuti

giovanni.ricevuti@unipv.it

1 Department of Biology and Biotechnology, University of Pavia, Pavia, Italy

2 Department of Neurosciences, Biomedicine and Movement Sciences, University of Verona, Verona, Italy

3 School of Pharmacy, Department of Drug Science, University of Pavia, Pavia, Italy

4 Almo Collegio Borromeo, Pavia, Italy
Dear Editor,

Following the very recent paper by Bonaventura et al., COVID-19 is considered an immuno-thrombotic disorder upon an inflammation response from endothelia [1]. Consequently, any therapeutic intervention aimed at preventing disease exacerbation and reduce hospitalization should target the endothelia-platelet cross talk and the immunity involvement in the thrombotic events within microcirculation. Actually, systemic endotheliitis, cytokine storm and activation of coagulation and complement cascades are the main cause of death from COVID-19. High concentration of plasma angiotensin II (a result of ACE2 decreased activity due to infection), increased D-dimer levels and an overall inflammatory response are the main responsible causes for COVID-19-induced immune-thrombosis [1]. Moreover, the early stages of severe COVID-19 progressing depend on the involvement of immune response and pro-oxidant agents, which impair the interrelationship between endothelia and platelets, then affecting the coagulation-fibrinolytic pathways. Antioxidants targeting the endothelial physiology are of major interest, in this respect. $\mathrm{O}_{2} / \mathrm{O}_{3}$ therapy is an old antioxidant treatment that has been used in COVID-19 patients first in Italy and then applied in several countries. Accordingly, authors assessed the effectiveness of oxygen-ozone autohemotherapy in restoring the normal levels of endothelia prostacyclin synthesis and in reducing the progress of COVID-19 in hospitalized patients [2, 3]. Moreover, the major blood intermediate of ozone, namely 4-HNE, modulates the increase of nitric oxide (NO) in endothelia by tuning the levels of $\mathrm{H}_{2} \mathrm{O}_{2}$, via the stimulation of eNOS phosphorylation. 4-HNE-mediated uncoupling of eNOS via the tetra-hydrobiopterin (BH4) depletion and the consequent inhibition of eNOS-S1179 phosphorylation, is a counterregulatory mechanism, which is highly dependent on both ozone levels and ozone therapy protocols and is regulated by vitamin $\mathrm{C}$ [2]. Therefore, the action of ozone via autohemotherapy must be finely regulated and the most proper protocol may make the difference. Additionally, since $\mathrm{O}_{3}$ can 
cause toxicity when administered at the wrong dosages or in case of inhalation, a fine balancing of the $\mathrm{O}_{2} / \mathrm{O}_{3}$ autohemotherapy mixture is also critical.

Besides the already described direct advantages of $\mathrm{O}_{2} /$ $\mathrm{O}_{3}$ therapy in endothelia homeostasis, oxygen-ozone treatment might have many other benefits as well. Indeed, upon COVID-19 infection, the inflammatory oxidants/antioxidants balance is deeply shaken, particularly in critically ill patients. Several studies have demonstrated that the new coronavirus suppresses the Nrf2 antioxidant pathway, one of the major buffers against oxidative stress control and toxicity (Fig. 1). Concurrently, NF-kB upregulation and an overall transcriptomic shift in favor of pro-inflammatory pathways are also observed (Fig. 1). Moreover, in severe COVID-19 patients, a marked imbalance in neutrophil-lymphocyte ratio, much in favor of the former, has been linked to extensive neutrophil lung infiltration, with higher risk of a fatal outcome (Fig. 1). When activated, neutrophils produce and release the so-called neutrophil extracellular traps (NETs) during the NETosis process. Normally, granulocytes exploit ROS and NETs to protect the organism when attacked by bacteria or viruses, but when excessive this response creates side effects. Higher than normal levels of circulating NETs have been found to correlate with neutrophil ROS production and, finally, to COVID-19 severity. Together, antioxidant Nrf2 downregulation, NF-kB overexpression and imbalanced redox homeostasis, are all responsible for tissue damage, blood cell dysfunction and disease worsening (Fig. 1). We thus postulate that, besides IFN- $\alpha$ and other pro-inflammatory cytokines, excessive ROS production might be one of the leading determinants of COVID-19 severity and thromboembolic manifestations in critically ill patients. In this respect, the antioxidant, anti-apoptotic and pro-autophagy properties of $\mathrm{O}_{2} /$ $\mathrm{O}_{3}$ therapy might be an asset against SARS-CoV2 infection. Moreover, its well-known cytoprotective activity has been shown to reduce COVID-19-caused organ damage through NF-kB downregulation and Nrf2 pathway modulation. The transcription factor $\mathrm{Nfr} 2$ in turn inhibits $\mathrm{NF}-\mathrm{kB}$, regulates the gene expression of a wide variety of antioxidant cytoprotective enzymes via ARE DNA binding site, normalizes altered

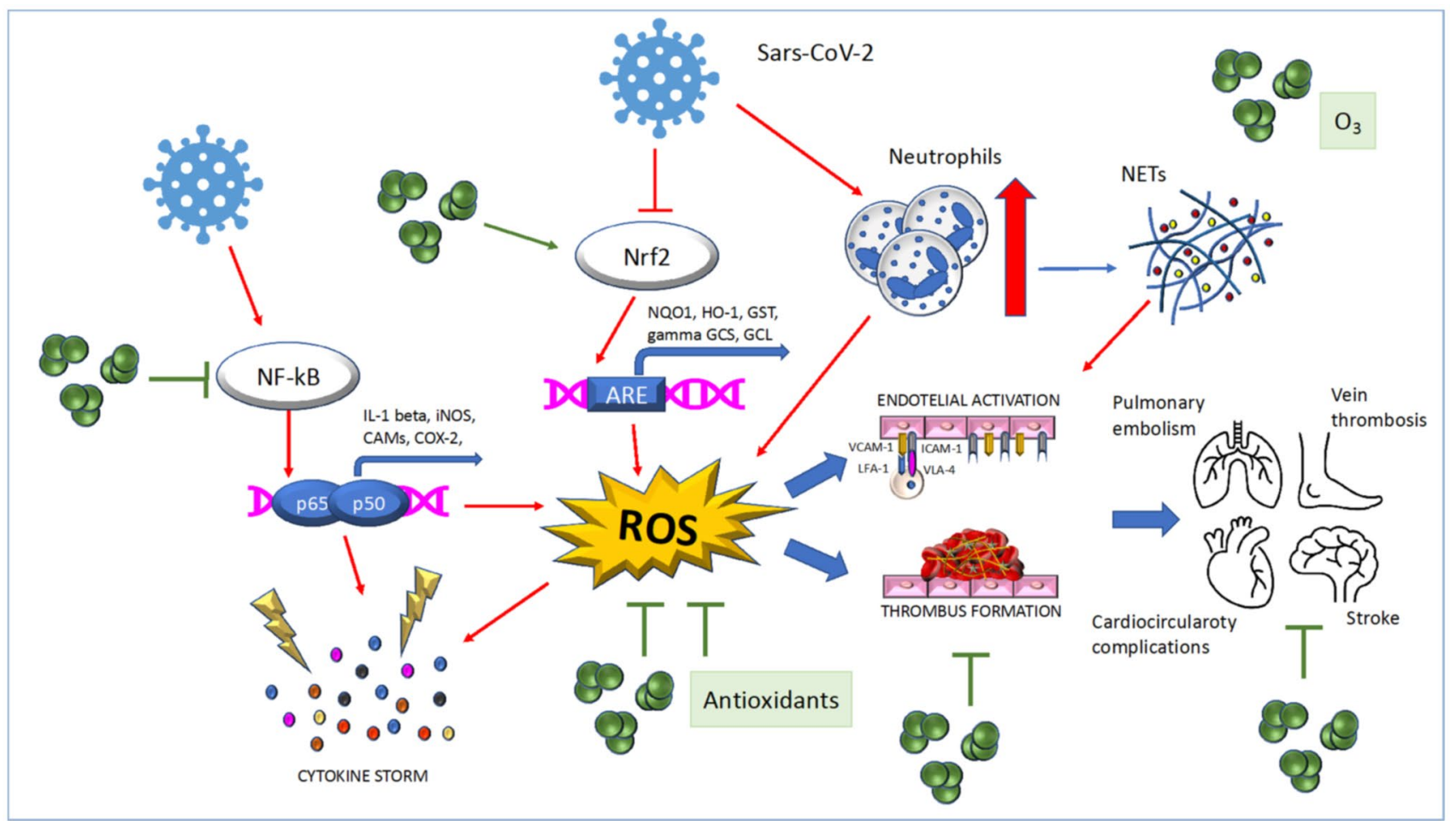

Fig 1 Sars-CoV-2 infection causes an imbalance in redox homeostasis that can be re-established by $\mathrm{O}_{2} / \mathrm{O}_{3}$ therapy. $\mathrm{Nrf} 2$ antioxidant pathway reduction, NF-kB-mediated inflammation increase, high neutrophil to lymphocyte ratio and more circulating NETs are all consequences of SARS-CoV2 infection. The subsequent ROS bursts favors the cytokine storm together with NF-kB pathway, thus further enhancing inflammation. At the same time, all these events lead eventually to endothelial activation and thrombus formation, contributing to COVID-19-induced complications, such as pulmonary embolism, stroke, deep vein thrombosis and cardiovascular complications. The antioxidant, anti-inflammatory and anti-thrombotic effects of oxygenozone therapy can re-establish the right redox balance, reduce the inflammation and avoid the COVID-19-mediated thromboembolism, hence restoring tissue homeostasis Adapted from Laforge $\mathrm{M}$, et al. Tissue damage from neutrophil-induced oxidative stress in COVID19. Nat Rev Immunol. 2020;20:515-516. https://doi.org/10.1038/ s41577-020-0407-1 
responses and inhibits SPIKE-ACE2 contact, thus establishing a positive antiviral loop [3].

Since ROS are important modulators of fibrinolysis, coagulation, platelets motility, complement activation and endothelial cell homeostasis, severe COVID-19 is often characterized by thrombotic complications such as pulmonary embolism, deep vein thrombosis, stroke and cardiocirculatory disorders (Fig. 1). Because of an even partial blood vessel occlusion, critically ill COVID-19 patients are characterized by ventilation perfusion (V/Q) mismatch and consequent hypoxemia [4]. Although invasive and noninvasive ventilation are currently used in the SARS-CoV2 clinical practice, they often fail to prevent death and reverse V/Q mismatch. Moreover, as the etiopathogenetic causes leading to COVID-19 are of endothelial-thrombogenic nature, a direct intervention on these mechanisms should be preferable. In this respect, $\mathrm{O}_{2} / \mathrm{O}_{3}$-mediated $\mathrm{Nrf} 2$ upregulation and ozone itself are both capable of inhibiting plateletsdependent thrombosis via enhanced $\mathrm{HO}-1$ production [3].
Furthermore, $\mathrm{O}_{3}$ inhibition of HIF- $1 \alpha$, one of the leading molecules controlling $\mathrm{O}_{2}$ sensing and hypoxic response, candidates $\mathrm{O}_{2} / \mathrm{O}_{3}$ therapy as a promising strategy against COVID-19-induced hypoxemia.

Altogether, the ability to act on many disease causative pathways at the same time candidates $\mathrm{O}_{2} / \mathrm{O}_{3}$ therapy as a convenient additional treatment to the current standard of care in moderate to severe COVID-19, as several studies reported [2, 3, Table 1]. For example, when tested in 50 COVID-19 patients aged over 60, with acute respiratory disease syndrome (ARDS) and hospitalized in intensive care unit, a significant decrease in pro-inflammatory molecules (i.e., CRP and IL-6) and thromboembolic markers (i.e., D-dimer), as well as an important amelioration in gas exchange parameters (i.e., $\mathrm{SatO}_{2} \%$ and $\mathrm{PaO}_{2} / \mathrm{FiO}_{2}$ ratio) have been reported [2]. Other clinical data collected in Italy confirmed the same encouraging results (Scientific Society of Oxygen Ozone Therapy (SIOOT), Udine and Table 1). Additional clinical trials are also ongoing in different countries.

Table 1 Recent studies reporting the use of $\mathrm{O}_{2} / \mathrm{O}_{3}$ therapy in COVID-19 treatment

\begin{tabular}{|c|c|c|}
\hline Studies & No patients receiving $\mathrm{O}_{2} / \mathrm{O}_{3}$ & Results \\
\hline $\begin{array}{l}\text { Franzini M et al., Int Immunopharmacol. } 2020 \\
\text { Nov;88:106-879. https://doi.org/10.1016/j. } \\
\text { intimp.2020.106879 }\end{array}$ & $\begin{array}{l}\text { Case series study, observational } \\
50 \text { males (mean age } 75 \text { ), hospitalized in ICU }\end{array}$ & $\begin{array}{l}\text { - Decrease in IL-6, D-dimer, } \mathrm{LDH}, \mathrm{CRP} \text {, } \\
\text { inflammation } \\
\text { - Improvement in } \mathrm{SatO} 2 \%, \mathrm{PaO}_{2} / \mathrm{FiO}_{2} \text {, recov- } \\
\text { ery time }\end{array}$ \\
\hline $\begin{array}{l}\text { Shah M et al., Int Immunopharmacol. 2021 } \\
\text { Feb;91:107-301. https://doi.org/10.1016/j. } \\
\text { intimp.2020.107301 }\end{array}$ & $\begin{array}{l}\text { Case series study, observational } \\
60 \text { patients (aged 30-60), mild to moderate } \\
\text { COVID-19 }\end{array}$ & $\begin{array}{l}\text { - Decrease in CRP, } \mathrm{LDH} \text {, ferritin } \\
\text { - Improvement in recovery time, RT-PCR } \\
\text { negativization, } \mathrm{SpO}_{2}\end{array}$ \\
\hline $\begin{array}{l}\text { Hernández A et al., Int Immunopharmacol. } \\
\text { 2021 Jan;90:107-261. https://doi.org/10. } \\
\text { 1016/j.intimp.2020.107261 }\end{array}$ & $\begin{array}{l}\text { Case studies } \\
9 \text { hospitalized }\end{array}$ & $\begin{array}{l}\text { - Decrease in D-dimer, ferritin. LDH, CRP } \\
\text { - Improvement in recovery time }\end{array}$ \\
\hline $\begin{array}{l}\text { Zheng Z et al., J Med Virol. } 2020 \\
\text { Nov;92(11):2348-2350 } \\
\text { https://doi.org/10.1002/jmv.26040 }\end{array}$ & $\begin{array}{l}\text { Case studies } \\
3 \text { males (one aged } 53 \text { and two aged 66) with } \\
\text { pneumonia }\end{array}$ & $\begin{array}{l}\text { - Decrease in } \mathrm{LDH}, \mathrm{CRP} \\
\text { - Improvement in } \mathrm{SatO}_{2} \%, \mathrm{PaO}_{2}\end{array}$ \\
\hline $\begin{array}{l}\text { Fernández-Cuadros ME et al., SN Compr Clin } \\
\text { Med. 2021 Mar 22:1-15. https://doi.org/10. } \\
\text { 1007/s42399-021-00849-9 }\end{array}$ & $\begin{array}{l}\text { Case series study, observational } \\
14 \text { patients }\end{array}$ & $\begin{array}{l}\text { - Decrease in LDH, CRP, D-dimer, IL-6, } \\
\text { fibrinogen } \\
\text { - Improvement in } \mathrm{SatO}_{2} \% \text {, lymphocytes \% }\end{array}$ \\
\hline $\begin{array}{l}\text { Çolak Ş et al., Int J Clin Pract. } 2021 \\
\text { Aug;75(8):e14321. https://doi.org/10.1111/ } \\
\text { ijcp.14321 }\end{array}$ & $\begin{array}{l}\text { Case series study, observational } \\
37 \text { patients }\end{array}$ & - Decrease in D-dimer, ferritin, IL-6 \\
\hline $\begin{array}{l}\text { Sozio E et al., Int Immunopharmacol. } 2021 \\
\text { Sep;98:107874. https://doi.org/10.1016/j. } \\
\text { intimp.2021.107874 }\end{array}$ & $\begin{array}{l}\text { Randomized controlled study: } 48 \text { patients }+44 \\
\text { controls (in the control group higher steroids } \\
\text { were used) }\end{array}$ & $\begin{array}{l}\text { - Clinical improvement at day } 7 \text { from randomi- } \\
\text { zation }\end{array}$ \\
\hline $\begin{array}{l}\text { Tascini C et al., Intern Emerg Med. } 2021 \\
\text { Apr;16(3):669-675. https://doi.org/10.1007/ } \\
\text { s11739-020-02542-6 }\end{array}$ & $\begin{array}{l}\text { Case series study Observational } \\
30 \text { severe patients }\end{array}$ & $\begin{array}{l}\text { - Decrease in IL-6 and IL-1beta } \\
\text { - Improvement in SIMEU clinical phenotype }\end{array}$ \\
\hline $\begin{array}{l}\text { Sharma A et al., Eur Rev Med Pharmacol Sci. } \\
\text { 2021 May;25(9):3632-3639. https://doi.org/ } \\
\text { 10.26355/eurrev_202105_25847 }\end{array}$ & $\begin{array}{l}\text { Case series, observational } \\
10 \text { patients with pneumonia }\end{array}$ & $\begin{array}{l}\text { - Decrease in CRP, D-Dimer, IL- } 6 \\
\text { - Improvement in } \mathrm{SpO}_{2} / \mathrm{FiO}_{2} \text { ratio, chest } \mathrm{X} \text { rays } \\
\text { infiltrates }\end{array}$ \\
\hline Hendawy HA et al., SN Compr Clin Med. & Case Study ( 1 female aged 60, hypertensive & - Rapid improvement in $\mathrm{SpO}_{2} \%$ \\
\hline
\end{tabular}
2021 Apr 14:1-4. https://doi.org/10.1007/ s42399-021-00895-3 and 1 male aged 40)

$\mathrm{CRP}$ C-reactive protein, $\mathrm{SatO} \%$ saturation of oxygen in percentage, $\mathrm{SpO}_{2}$ oxygen saturation, $\mathrm{PaO}_{2}$ arterial oxygen partial pressure in mmHg, $\mathrm{FiO}_{2}$ fractional inspired oxygen, $\mathrm{SpO}_{2}$ oxygen saturation, $\mathrm{SIMEU}$ Italian society of emergency and urgency medicine 
As of July 31, 2021, a total of 8 studies are reported on clinicaltrials.gov: 3 not yet recruiting, 3 recruiting and 2 completed. Although more research is certainly needed to confirm the validity of this approach, $\mathrm{O}_{2} / \mathrm{O}_{3}$ therapy might offer enough benefits to be used as adjuvant treatment.

Some limitations in ozone studies are to be reported, yet. In this Letter, we focused onto the major studies so far published, with high reliability and soundness, so we did not report further ongoing research investigations for brevity and space constraint. Leading reviews about the application of ozone in COVID-19 have been also published and a recent narrative and extensive overview has been reported by our group [3]. So far, no evidence was for example reported about the effectiveness of oxygen-ozone therapy in ST elevation myocardial infarction (STEMI) within cohorts of COVID-19 asymptomatic patients. Actually, recent reports have reported that in asymptomatic STEMI patients, greater thrombotic formations, higher viral load in thrombi (SARSCoV2 colonizes thrombi) and poorer myocardial blush grade, are collectively present [5]. To date, the use of oxygen-ozone therapy combined with conventional therapy, should prevent SARS-CoV2 induced immune-thrombosis, as ozone is not merely a thrombolytic (clot-dissolving) agent, yet evidence was reported that ozone may activate thrombolysis (see ref. [3] for a review).

In conclusion, the antioxidants, anti-inflammatory and anti-thrombotic properties of oxygen-ozone therapy might be crucial against COVID-19-induced hyperinflammation, immunodeficiency, hypercoagulability and poor response to therapies. Based on the first published studies, we, thus, propose $\mathrm{O}_{2} / \mathrm{O}_{3}$ treatment as a promising adjuvant therapy in mild to severe cases of SARS-CoV2 infection, and we call for its consideration in the clinical practice.

Author contributions All authors contributed equally in writing and revising the manuscript. All authors read and approved the final manuscript.

Funding There was no funding for this article.
Code availability Not applicable.

\section{Declarations}

Conflict of interest The authors declare that they have no competing interests.

Ethical approval Not applicable.

Consent to participate Not applicable.

Consent for publication Not applicable.

\section{References}

1. Bonaventura A, Vecchié A, Dagna L, Martinod K, Dixon DL, Van Tassell BW, Dentali F, Montecucco F, Massberg S, Levi M, Abbate A (2021) Endothelial dysfunction and immunothrombosis as key pathogenic mechanisms in COVID-19. Nat Rev Immunol 21(5):319-329. https://doi.org/10.1038/s41577-021-00536-9

2. Franzini M, Valdenassi L, Ricevuti G, Chirumbolo S, Depfenhart $\mathrm{M}$, Bertossi D, Tirelli U (2020) Oxygen-ozone $\left(\mathrm{O}_{2}-\mathrm{O}_{3}\right)$ immunoceutical therapy for patients with COVID-19 Preliminary evidence reported. Int Immunopharmacol 88:106879. https://doi.org/10. 1016/j.intimp.2020.106879

3. Chirumbolo S, Valdenassi L, Simonetti V, Bertossi D, Ricevuti G, Franzini M, Pandolfi S (2021) Insights on the mechanisms of action of ozone in the medical therapy against COVID-19. Int Immunopharmacol 96:107777. https://doi.org/10.1016/j.intimp. 2021.107777

4. Hua J, Qian C, Luo Z, Li Q, Wang F (2020) Invasive mechanical ventilation in COVID-19 patient management: the experience with 469 patients in Wuhan. Crit Care 24(1):348. https://doi.org/ 10.1186/s13054-020-03044-9

5. Marfella R, Paolisso P, Sardu C, Palomba L, D’Onofrio N, Cesaro A, Barbieri M, Rizzo MR, Sasso FC, Scisciola L, Turriziani F, Galdiero M, Pignataro D, Minicucci F, Trotta MC, D'Amico M, Mauro C, Calabrò P, Balestrieri ML, Signioriello G, Barbato E, Galdiero M, Paolisso G (2021) SARS-COV-2 colonizes coronary thrombus and impairs heart microcirculation bed in asymptomatic SARS-CoV-2 positive subjects with acute myocardial infarction. Crit Care 25(1):217. https://doi.org/10.1186/s13054-021-03643-0

Publisher's Note Springer Nature remains neutral with regard to jurisdictional claims in published maps and institutional affiliations.

Data availability Not applicable. 